\title{
Curriculum Change in English Language Curriculum Advocates Higher Order Thinking Skills and Standards-Based Assessments in Malaysian Primary Schools
}

\author{
Tajularipin Sulaiman (PhD)
}

tajulas@upm.edu.my

\author{
Ahmad Fauzi Mohd Ayub (PhD) \\ Sports Academy, Universiti Putra Malaysia, 43400 Serdang, Selangor, Malaysia \\ afmy@upm.edu.my \\ Suriati Sulaiman \\ Faculty of Educational Studies, Universiti Putra Malaysia, 43400 Serdang, Selangor, Malaysia \\ sulaimansuriati@yahoo.com
}

\section{Doi:10.5901/mjss.2015.v6n2p494}

\section{Abstract}

Malaysia undertook a comprehensive reform of the primary education by introducing KSSR or the Primary School StandardsBased Curriculum in 2011. The curriculum change has largely driven by the setting of national standards for KSSR subjects. Accordingly, the Standards-Based English Language Curriculum (SBELC) was designed with significant changes in curriculum documents and organization. SBELC not only demands changes in teacher knowledge, attitudes, and instructional practices but also seeks teachers to design such activities and assessments that require pupils to comprehend the language input and answer questions with high levels of cognitive skills that emphasize on conceptual understanding and integration of many language skills and language focus rather than traditional rote learning skills. The purpose of this paper is to review curriculum change in the new English language curriculum in which higher order thinking skills and standards-based assessments are given due attention in Malaysian primary schools.

Keywords: Curriculum change, curriculum implementation, standards-based curriculum, standards-based assessment, English language curriculum, English literacy

\section{Introduction}

Malaysia undertook a comprehensive reform of the primary education system which encompassed structural and curriculum change by introducing KSSR (Kurikulum Standard Sekolah Rendah) or the Primary School Standards-Based Curriculum in 2011 starting Year 1 cohort. With the emergence of KSSR, the Standards-Based English Language Curriculum (SBELC) was designed as well with significant changes in curriculum documents and organization. Accordingly, the Standard Document was developed and becomes the blueprint of the English language curriculum for Years 1 to 3 . Besides, the curriculum is organized in modular structure with modularity of focus. Part of the curriculum change involves the inclusion of basic reading literacy, phonics, penmanship, and language arts as the new curriculum content. In addition to that, the SBELC gives emphases on critical and creative thinking skills as well as reasoning skills that are incorporated in the learning standards to enable pupils to solve simple problems, make decisions and express themselves creatively in simple language (Curriculum Development Division, 2011). There are different types of learning required different teaching strategies and no single method works for all learning. Furthermore, the new English language curriculum itself demands teachers to design such activities and assessments that require pupils to comprehend the language input and answer questions with high levels of cognitive skills that emphasize on conceptual understanding and integration of many language skills and language focus rather than traditional rote learning skills. According to Swartz, R.J, Costa, A.L, Beyer, B.K, Reagan, R, \& Kallick, B. (2008), skillful thinking have three components which is thinking skills, habits of mind, and metacognition. Skillful thinking can and should be taught to student in the classrooms at every level. To encourage higher order thinking skills students must also receive challenging tasks, encouragement to stay on task when grappling with open-ended questions, and ongoing feedback about their progress. 


\section{Curriculum Change and Implementation}

Implementing a new curriculum demands teachers to move from the former programme to the new programme. Hence, implementing the new curriculum could be difficult and may take times because educational leaders need to convince the teachers to accept the curriculum and implement it as intended. In fact, curriculum implementation is a change process, and part of the change requires teachers to acquire new knowledge about the curriculum; however, mastering the new knowledge is not the only requirement for teachers to change (Ornstein \& Hunkins, 2014). Teachers generally resist to change because they are used to the former curriculum. If they have to adopt the new curriculum, they need to change their knowledge, attitudes and instructional practices and such expectation itself makes them feel uncomfortable. Therefore, to be able to change, teachers as key players in the curriculum implementation process need at first to understand the change and how it works.

McNeil (2009) identified several types of curriculum change according to its complexity: substitution, alteration, perturbations, restructuring, and value-orientation changes. Substitution occurs when a new element substitutes the other which is already present, such as, teachers are required to substitute a new textbook for an old one. Undoubtedly, this kind of change is the easiest to do by teachers and in fact, it is the most common type of change occurs in schools. Alteration exists when new content, items, materials, or procedures are added up into existing materials and programmes. The changes usually are minor, and thus, schools usually can adopt it instantly. Perturbations are changes that may at first interrupt the existing programme but later it can be attuned accordingly by teachers to the on-going programme within a short time span, for instance, teachers need to change their class schedules. The changes may affect the time allocated for teaching other subject or it may affect other teachers' class schedules but it could be adjusted shortly. Restructuring occurs when the changes modify the whole school system, such as, schools introduce a new curriculum to their teachers and pupils. The changes demand the teachers to adopt new concepts of teaching role, new curriculum content, and new text books. Value-orientation changes take place when teachers or school staffs are sought to adopt the new fundamental philosophies or curriculum orientations. The changes could occur if only they are willing to accept the new values otherwise the changes will be short-lived. In Malaysia context, the change in the English language curriculum can be classified as restructuring since it involves structural and curriculum change in which it modifies the existing curriculum documents and organization as well as introduces four language areas as the new curriculum content and this change takes place nation-wide.

To ensure that the curriculum change is successfully implemented, teachers should be dedicated to any changes occur in the curriculum and committed to implementing the new curriculum (Ornstein \& Hunkins, 2014). However, in the process, teachers may refuse to accept the changes for their very own reasons. As a matter of fact, frequently teachers view change as something that requires them to do more work which adds up to their already overloaded schedule. To them, curriculum change means they have to do extra work in the existing routine and this seeks them to sacrifice their time, energy, and even money to meet the new curriculum demand. Teachers may also deter change for they do not earn extra money or get any reward even though they do extra work or sacrifice their time, money or money to cope with the curriculum change. In fact, many teachers view new curriculum programmes signify new teaching skills to be learned, or new competencies to be developed which demand them to attend extra courses and workshops. It may be possible that teachers are most likely resist curriculum change because they do not have the knowledge and skills required by the new curriculum but at the same time, they do not want to be told that they are incompetent to teach the new curriculum. Furthermore, there is the likelihood that the new curriculum is implemented after a short notice or the training period is shorten due to budgetary constraints. Consequently, teachers are not adequately equipped before they are ready to deliver the new curriculum to their pupils.

\subsection{Standards-Based Curriculum}

Curriculum change in Malaysia has largely driven by the setting of national standards for KSSR subjects, in which the standards define what pupils should know and be able to do. These standards are later being used to guide other education system components: curriculum, instruction, assessment, and professional development. The standards-based system measures each pupil against the concrete standards. In KSSR, standards is a term which defines essential knowledge, skills, understandings and strategies that pupils need to learn as well as the degree or quality of proficiency that pupils need to display for a particular year (Curriculum Development Division, 2011).

Setting national standards is important for some reasons. Evidently, setting national standards allows equal opportunity for all pupils to learn and be assessed through the same standards (Steiner, 2013). If there are no common standards established, teachers may need to set their own standards based on what the schools demand on their pupils. 
Consequently, instruction and assessment cannot be consistent at national level since there are different standards for different groups of pupils. National standards also provide clear, measurable standards for all pupils to know what they should acquire and be able to do at different levels of their education. Eventually, to measure whether the pupils learning progress meets the performance standards, standards-based assessments are designed at the end of the learning episode. In KSSR, pupils who are not achieving the standards will be provided with early, effective remedial support until they are able to meet the standards (Ministry of Education, 2012).

Setting standard seems imperative in the English language curriculum because they express clear expectations of what all pupils should learn and be able to do with the language (Steiner, 2013). The curriculum standards may benefit different populations which range from state, districts, schools, pupils, to parents (Harris \& Carr, 1996) in different ways. For example, state can use the standards as a common reference tool and defined framework to set up national assessments. In districts and schools, teachers may use the standards to focus on new ways to organize curriculum content, instructional programmes and assessment plans at school level. Standards may also help teachers design classroom instructions and assessments on the basis of what is important for pupils to learn. They also enable teachers to tell pupils what are expected from them; by knowing the expectations clearly pupils may eventually improve their learning. For pupils, standards set clear performance expectations. Through the standards, pupils know what they should learn and be able to do to meet the standards. For parents, standards allow them to know how their children are progressing in their learning.

In Malaysia, the KSSR has presented a different view of English language learning, teaching and assessment that shifts the focus away from memorization and rote learning toward standards-based approach. There are several forces promoting this shift, including the global challenges of the $21^{\text {st }}$ century, recent advances in theories of learning, the dawning of the information age, the New Economic Model and UNESCO four pillars of education: learning to know, learning to do, learning to live together and learning to be. Generally, the national standards for English language curriculum, instruction, and assessment were developed on the basis of these inquiries:

- What do pupils need to know about the English language, and what should they be able to do?

- How do we determine when pupils know the English language that we want them to know and be able to do?

- What do we want the English teachers to know and be able to do?

The responses to these questions are contained in the two standard documents: the Standard Document for Primary School English Language Curriculum and the Performance Standard Document for English Language. These documents are based on theories and practices of teaching English as a second language (TESL) in primary schools.

At foundation level, the standards-based English language curriculum defines what pupils are expected to do at different levels of performance in five language strands: listening, speaking, reading, writing, and language arts. The new curriculum gives emphasis on the development of critical literacy particularly reading through phonics approach. During reading lessons, teachers will teach beginning reading through phonics in a fun-filled way and provide opportunities for pupils to apply knowledge of phonics in reading practice as well as demonstrate understanding of the reading texts using dictionary skills, word recognition and word attack skills to construct meaning. These opportunities are essential for producing pupils who are able to read independently for information and enjoyment by the end of the 6-year primary schooling.

\subsection{Standards-Based Assessment}

In Malaysia, performance standard document for KSSR subjects was developed as a reference tool for teachers to improve the school-based assessment aligned with the implementation of standards-based assessment. Performance standard is a statement on the level of development of pupils as measured by the standards and shows the position of pupils in the stage of learning development or progress. Development in the standards is divided into two, namely, the horizontal development (construct) and vertical development (band). The Band is a label used to indicate certain benchmarks that are arranged in a hierarchy in order to be used for the purpose of reporting the learning progress of individual pupils. The progress of the pupils is explained in one or more qualifier using a word or phrase that correctly describes the standards in the form of learning outcomes.

Standards-based assessment is a process to obtain information about the degree to which pupils know and are able to do or have mastered what they have learned according to specific levels of achievement, as intended by the English language curriculum (Ministry of Education, 2011). To incorporate content, learning, and performance standards into curriculum programmes, the focus must be on designing assessments that promote pupils' learning and allow them to demonstrate the skills of thinking, communication, and application (Woodley \& Ferguson, 2003). Likewise, in the standards-based English language curriculum, pupils' product and performance are compared to the performance 
standards which are directly linked to the content and learning standards. Pupils' learning development is reported using specific benchmarks which are defined in the Performance Standard Document for English Language (Ministry of Education, 2011). The benchmarks are arranged in hierarchal order in six bands: know (Band 1), know and understand (Band 2), know, understand and apply (Band 3), know, understand and apply using good manners (Band 4), know, understand and apply using admirable manners (Band 5), and know, understand and apply using exemplary manners (Band 6).

A focus on designing assessments is imperative to evaluate enduring understanding, considering pupils' prior knowledge, focusing on teachers' instruction, and creating an interconnected programme that allows teachers to report pupils' learning progress accurately against the content standards (Woodley \& Ferguson, 2003). In addition to that, to encourage and promote pupils' success in learning, teachers may use different strategies in conducting diagnostic, formative, and summative assessments. Correspondingly, multiple sources of learning evidence like checklists, observations, presentations, quizzes and written tasks could be used to document the attainment of the standards. The forms of group work found to be effective for the development of higher order thinking skills include student discussions, peer tutoring, and cooperative learning. Through the process, teachers may develop language profiles that record pupils' language development and assess them individually.

In the standards-based English language curriculum, formative and summative assessments are used to assess pupils' competence in the language. Formative assessment, which is school-based, is an important aspect of KSSR. This type of assessment aims at gauging each pupil's learning progress from everyday classroom activities in which pupils may produce some creative works, higher order thinking skills tasks or may perform in fun-filled activities. At the same time, the outcome of the assessment helps teachers to reflect their teaching and learning strategies and techniques and eventually encourages effective instruction and meaningful language practices as well as enhances language learning in the classroom. Whereas, summative assessment, another type of school-based assessment that is conducted at the end of a school year, demands teacher to design assessment that requires pupils to answer questions with high levels of cognitive skills including critical and creative thinking skills as well as reasoning skills.

\subsection{Primary School Standard Curriculum (KSSR)}

In the process of transforming the primary school curriculum, the Ministry of Education (MOE) had conducted benchmarking with school curriculum of several developed countries such as Singapore, New Zealand, United Kingdom, and Australia to ensure that the new primary school curriculum does not only cater local needs but also meets international benchmarks so that the new curriculum will be on par with the global education. The MOE also obtained inputs from various stakeholders such as non-governmental organizations, industry, academicians, and parents. Based on the inputs, the concept of standard-based curriculum for primary schools was then developed. Later, the concept of standards-based curriculum for primary schools was approved in National Curriculum Committee meeting on October 2, 2009. The new curriculum was launched as the Primary School Standards-Based Curriculum or locally known as KSSR. The KSSR was developed based on the principles of the former primary school curriculum, Kurikulum Bersepadu Sekolah Rendah (KBSR) or the Primary School Integrated Curriculum, the National Education Philosophy and National Education Policy. To ensure that the new curriculum is well established, a pilot study was administered at selected primary schools throughout the country.

KSSR takes into account the global challenges of the 21 $1^{\text {st }}$ century, the New Economic Model and present-day learning theory. The new national curriculum also adopts UNESCO four pillars of education, namely learning to know, learning to do, learning to live together and learning to be. Through the standards-based curriculum, KSSR aspires to produce balanced individuals in terms of intellectual, spiritual, emotional, social, and physical which further creates responsible citizens, global players, and knowledgeable workers.

Yet, KSSR still upholds all principles of the KBSR curriculum which are included: (1) integrated approach; (2) individual development as a whole; (3) fair education for all students; and (4) education for life. Such principles are sustained as they are still appropriate and relevant to produce balanced and holistic individuals. The main focus of KSSR is the curriculum contents are delivered in integrated approaches. The elements of knowledge, skills and values are combined as to create unity in terms of physical, emotional, spiritual, intellectual, and social aspects. The integrated concept may occur through skills cohesion either in one subject or between subjects. For instance, in the teaching of English language, the four main skills, namely, listening, speaking, reading, and writing are emphasized. However, in one teaching and learning session, cohesion of only two skills is highlighted, for example, listening and speaking or reading and writing. Cohesion between subjects can occur, for example, singing is used in teaching English.

Besides, KSSR is formulated in order to ensure that all subjects including English language play an important role 
in fulfilling the physical, emotional, spiritual, intellectual, and social needs of the pupils. According to Gardner (2004), every pupil is a unique individual with at least eight core intelligences: verbal-linguistic, logical-mathematical, visualspatial, bodily-kinaesthetic, musical-rhythmic, interpersonal, intrapersonal and naturalist. Yet, individual potentials cannot be developed in isolation (Armstrong, 2009). Hence, in English language classrooms, pupils may develop their higher order thinking skills and potentials holistically providing that they are given opportunities to master the English language through varied teaching strategies and learning activities.

In addition, KSSR gives fair opportunity to all pupils to obtain the knowledge and skills that are comprehensive and well balanced. In this context, the English language is taught to all pupils in primary schools as a compulsory subject. KSSR also provides the knowledge and skills needed by pupils as a basis to meet the challenges of everyday life and lifelong education. As far as the English language teaching and learning is concerned, pupils are trained to master the four basic skills namely listening, speaking, reading, and writing skills so that they are able to comprehend any kind of information either in spoken or written language in their daily life.

On top of that, KSSR aims to produce a balanced, creative, critical and innovative individual through six strands: (1) communications; (2) science and technology; (3) physical and aesthetic development; (4) personal skills; (5) humanity and spirituality; and (6) attitudes and values. The concept of strand focuses on the formation of balanced human capital in terms of physical, emotional, spiritual, intellectual and social. The strands represent areas of knowledge, skills and values that form the basis for the development of a creative, critical and innovative individual; hence need to be mastered by all pupils. Each strand is mutually interconnected and integrated. However, the strand of communication is very significant to this study because it deals with the English language curriculum indeed. The strand gives emphasis on establishing a process to combine the language skills in the forms of verbal and non-verbal during interaction. Furthermore, it focuses on specific language skills such as listening and speaking, reading and writing, as well as the value-added skill that is reasoning skill. Pupils need to master these skills to help them in the process of acquisition of knowledge, skills and values in other strands. Mastering in language skills will prepare the pupils to make accurate and systematic language choice in social interaction.

With the emergence of KSSR, the standards-based English language curriculum (SBELC) was designed and was first enacted to Year 1 cohort in 2011. At the time of this publication, the new English language curriculum is being implemented in Years 1 to 4 of Malaysian primary schools, regardless of whether they are National or National-type schools, as an innovative and potential curriculum for further developing students' proficiency in the English language. The significant change in national curriculum has great implication on the English language curriculum and teaching which requires significant change in teachers' knowledge, attitudes, and instructional practices.

\subsection{Standards-Based English Language Curriculum (SBELC)}

English is taught as a second language (ESL) in all Malaysian primary schools. Pupils usually acquire the first language that is something other than English such as Malay, Chinese, and Tamil. They are referred to as second language learners (SLL) and are often designated as ESL in order to receive accommodations and support with their language acquisition goals. The mastery of English is seen essential for pupils in order to gain access to information and knowledge written in English. In ESL classrooms, pupils are usually taught to become fluent in written and spoken English. The expression second language also connotes that English is the second most important language in Malaysia, after the national language, Bahasa Malaysia and the first foreign language learnt by many pupils after their mother tongue as well (Chitravelu, Sithamparam, \& Choon, 2005). Furthermore, English is offered as a core as well as compulsory subject to primary school pupils.

In line with the government's policy on strengthening English, a new English language curriculum for primary schools was designed to produce pupils who will be more proficient in the language. Generally, the goal of the new English language curriculum is to help pupils acquire the language so that they can use it in their daily lives, and for studies as well as work purposes (Curriculum Development Division, 2011). Furthermore, in this era of globalization, mastering the English language is an advantage to pupils since they can have easy access to information that is available on the electronic media such as the Internet for English is the dominant language used in such media.

The standards-based English language curriculum aims to equip primary pupils with basic language skills: listening, speaking, reading, and writing to enable them to communicate effectively in a variety of contexts that is appropriate to their level of development (Curriculum Development Division, 2011). In other words, once they have completed the 6-year primary education, pupils are expected to be able to communicate with peers and adults confidently and appropriately in formal and informal situations, read and comprehend a range of English texts for information and enjoyment, write a range of texts using appropriate language, style and form through a variety of media, appreciate and 
demonstrate understanding of English language literary or creative works for enjoyment, and use correct and appropriate rules of grammar in speech and writing (Curriculum Development Division, 2011).

The new English language curriculum for national primary schools (SK) is designed to provide pupils with a strong foundation in the language. Teachers are recommended to use Standard British English in the teaching and learning of English language. It should also be used as a reference tool for spelling, grammar, and pronunciation for standardization. In Year 1, the English language curriculum emphasizes on the development of strong foundation in basic language skills so that pupils may further build their proficiency in the language in Level 2. At this foundation level, pupils of national primary schools spend about 300 minutes per week to cover four modules: (1) listening and speaking; (2) reading; (3) writing; and (4) language arts. The design of these modules is specifically meant to help the pupils acquire basic literacy skills in the English language as early as in their first year of primary education.

The introduction of the standards-based English language curriculum for Malaysian national primary schools has involved some significant changes in terms of curriculum documents and organization. The KSSR English language curriculum was documented comprehensively in the Standard Document for Primary School Curriculum: Basic Core Module of English Language for National Primary Schools or Dokumen Standard Kurikulum Sekolah Rendah: Modul Teras Asas Bahasa Inggeris SK in 2011. The document lays out the English language curriculum for Years 1 to 3. As for former English language curriculum, the syllabus, objectives and learning outcomes were documented in the Curriculum Specifications.

Another significant change in the standards-based English language curriculum is the curriculum organization. SBELC is designed in a modular structure with modularity of focus and this is reflected in the organization of the content and learning standards. By organizing the language curriculum into four modules, Year 1 pupils are able to focus on the development of specific language skills under each module through purposeful and meaningful activities. This modular approach also encourages skill integration. However, skill integration is exploited strategically to enhance pupils' development of specific language skills as described in the content and learning standards in the module.

In order to make learning more meaningful and purposeful, English language input is presented under themes and topics which are appropriate for Year 1 pupils. Three broad themes identified in the English language curriculum are: (1) world of self, family, and friends; (2) world of stories; and (3) world of knowledge. The themes and topics are covered in all four modules: listening and speaking, reading, writing, and language arts.

Change in the curriculum organization also involves inclusion of basic reading literacy through phonics, penmanship, and language arts as the new curriculum content. The emphases on those language areas are prescribed in learning standards for reading (basic reading literacy and phonics), writing (penmanship) and language arts (language arts). English literacy is given due attention in the new English language curriculum, and is therefore recognised as the key feature of Shift 2 in the Malaysian Education Blueprint 2013-2025 which seeks to ensure that every child is proficient in the English language (Ministry of Education, 2012). The introduction of literacy in English at foundation level of learning is to increase English literacy rates among all Level 1 primary school pupils with exception of special needs pupils (Curriculum Development Division, 2014).

\subsection{English Literacy}

English literacy becomes the core element in the new language curriculum because the best time to address literacy problems in national primary school is at the foundation level of learning, which is Years 1 to 3 (Curriculum Development Division, 2014). The Ministry of Education believes that by nipping the problem at its bud, illiteracy in English can be eradicated and pupils will be able to read proficiently by the end of their primary schooling. In fact, language acquisition experts suggest that the best time to start learning a second language is as early as possible before they reach puberty (Lightbown \& Spada, 2013). Since majority of the pupils do not grow up in English-speaking environment, they do not attain literacy in the English language until they go for formal schooling (Gan, Muniandy, \& Wan Yahaya, 2013). In addressing the basic reading literacy problems in Year 1, teachers are recommended to employ phonics instruction in order to teach beginning reading.

The teaching of basic reading literacy is addressed using phonics: with the teaching of phonemes and graphemes to develop letter-sound correspondence and decoding skills (Curriculum Development Division, 2011). Learning phonics is the main component of the KSSR reading skills and phonics itself is part of the new English language curriculum for primary schools, hence, phonics approach is suggested to be used as a strategy to instil basic reading literacy in young pupils. The phonics structure should be followed through systematically in the sequence as outlined in the English language curriculum standards. Teachers are recommended to explicitly teach one sound at a time and all 44 sounds of the English language are covered in two years in national primary schools. The phonics instruction places emphasis on 
the synthetic approach (Curriculum Development Division, 2014).

\section{Conclusion}

The Malaysian education system aspires to produce pupils who will be at minimum operationally proficient in Bahasa Malaysia as the national language and language of unity, and in English as the international language of communication. This means that upon leaving school, pupils are expected to be able to work in both a Bahasa Malaysia and English language environment. However, the current system produces commendably strong Bahasa Malasysia learning outcomes but not the English language. There is widespread operational proficiency in Bahasa Malaysia among pupils, but operational proficiency in English is, however, much lower (Ministry of Education, 2012). Hence, efforts at education reform to boost pupils' proficiency in English become the most immediate priority in the Standards-Based English Language Curriculum for primary schools. In addition to that, changes in the new English language curriculum may it be in curriculum content or teaching approach or assessment demand teachers and pupils to incorporate higher order thinking skills in teaching and learning of the English language at foundation level of primary education.

\section{References}

Armstrong, T. (2009). Multiple intelligences in the classroom(3rd ed.). Alexandria, VA: ASCD.

Chitravelu, N., Sithamparam, S., \& Choon, T. S. (2005). ELT methodology: Principles and practice (2nd ed.). Shah Alam, Malaysia: Oxford Fajar Sdn. Bhd.

Curriculum Development Division. (2011). Standard Document of Primary School Curriculum: Basic Core Module of English Language for National Schools. Putrajaya: Author.

Curriculum Development Division. (2014). Literasi Bahasa Inggeris: Teacher's module [English literacy: Teacher's module]. Putrajaya: Author.

Gan, I., Muniandy, B., \& Wan Yahaya, W. A. J. (2013). A conceptual exploration: A phonics aerobic instructional approach for improving English language phonological awareness. Unpublished manuscript, Centre for Instructional Technology and Multimedia, Universiti Sains Malaysia.

Gardner, H. (2004). Frames of minds: The theory of multiple intelligences (20th Anniversary Edition). New York: Basic Books.

Harris, D. E., \& Carr, J. K. (1996). How to use standards in the classroom. Virginia: ASCD.

Lightbown, P., \& Spada, N. (2013). How languages are learned (4th ed.). Oxford: Oxford University Press.

McNeil, J. D. (2009). Contemporary Curriculum: In thought and action (7th ed.). Hoboken, NJ: John Wiley \& Sons.

Ministry of Education. (2011). Dokumen standard prestasi Bahasa Inggeris untuk kegunaan sekolah kebangsaan Tahun 1 [Performance standard document for Year 1 of national schools]. Putrajaya, Malaysia: Author

Ministry of Education. (2012). Preliminary report of Malaysia education blueprint 2013-2025. Putrajaya, Malaysia: Author.

Ornstein, A. C., \& Hunkins, F. P. (2014). Curriculum foundations, principles and issues (6th ed.). Essex: Pearson Education.

Steiner, J. (2013). Why have a standards-based curriculum and what are the implications for the teaching-learning-assessment process? Manuscript submitted for publication.

Swartz, R.J, Costa, A.L, Beyer, B.K, Reagan, R, \& Kallick, B. (2008). Thinking Based Learning : Activating Student's Potentials. Norwood, MA:Christopher-Gordon Publishers.

Woodley, L., \& Ferguson, A. (2003). Standards-based assessment: A model. A project granted by the Curriculum Services Canada Foundation, Canada. 